\title{
Land and Water Resources Planning and Management Options in Floodplain Wetlands in Nyando Basin, Kenya
}

\author{
Job Rotich Kosgei ${ }^{*}$ (D), Serena Adhiambo Nasongo ${ }^{2}$, Julius Kipkemboi ${ }^{3}$, Nzula Kitaka ${ }^{3}$, \\ Joash Barack Owuor-Okeyo² \\ ${ }^{1}$ Departmemt of Civil \& Structural Engineering, Moi University, Eldoret, Kenya \\ ${ }^{2}$ VIRED International, Kisumu, Kenya \\ ${ }^{3}$ Department of Biological Sciences, Egerton University, Nakuru, Kenya \\ Email: ^masultiony@gmail.com, adedeserena@gmail.com, jkipkemboi@kafuco.ac.ke,nkitaka@yahoo.com, jbokeyo@gmail.com
}

How to cite this paper: Kosgei, J.R., Nasongo, S.A., Kipkemboi, J., Kitaka, N. and Owuor-Okeyo, J.B. (2021) Land and Water Resources Planning and Management Options in Floodplain Wetlands in Nyando Basin, Kenya. Journal of Environmental Protection, 12, 1144-1160.

https://doi.org/10.4236/jep.2021.1212067

Received: October 15, 2021

Accepted: December 14, 2021

Published: December 17, 2021

Copyright $\odot 2021$ by author(s) and Scientific Research Publishing Inc. This work is licensed under the Creative Commons Attribution International License (CC BY 4.0).

http://creativecommons.org/licenses/by/4.0/ (c) (i) Open Access

\begin{abstract}
The functions of and services from wetlands are seriously compromised due land and water scarcity coupled with the inability of poor people to adopt sound management strategies. The expansion of rice irrigation into the Ombeyi wetland ecosystem is likely to reduce their long-term ecological functionality. Using field observations and measurements, stakeholder analysis framework and consultative fora, this study investigated the growth in irrigated agriculture, irrigation practices and existing and potential trade-offs between the various uses of the wetland and their ecological functions. The objective was to identify the equilibrium between expansion of area under rice and restoration of the Ombeyi wetland ecosystem. Issues affecting wetland use and management were identified and used to derive possible solutions that could lead to sustainable use of the wetlands. The study showed that the area under rice cultivation increased by up to $760 \%$ as compared to the 1970 s, most of it into the wetlands. There was a huge dependency on irrigation for food and income generation. However, there was observed low efficiency in water use and management. Recent emerging crops, especially arrow roots, would pose more threats to the wetland ecosystem because of their tolerance to waterlogged soils, low labour input, continuous harvesting and fewer pests and diseases. The fast exhaustion of soil fertility by arrow roots is also likely to motivate expansion into new areas, predominantly the wetlands. It was established that transplanting rice by mid May as opposed to the current practice in which farmers transplant in mid July saves water. The impact could further be reduced if the farmers adopted an optimized seasonal calendar. The study concluded that the solutions to wetland encroachment and over
\end{abstract}


exploitation of resources lie in capacity building of farmers, improving efficiency in resource use and seeking for alternative livelihood options.

\section{Keywords}

Irrigation, Livelihood Options, Rice, Stakeholders, Wetland

\section{Introduction}

In the year 2000, almost 190 countries committed, through the UN Millennium Development Goals (MDGs), to reduce by half the 800 million food insecure people. This compelled countries to enact policies, strategies and measures that would eradicate poverty and inequality as well as improve physical and economic access to sufficient, nutritionally adequate and safe food all the time. Because it is the responsibility of national governments to ensure that individuals attain food security [1], developing countries in Africa and South East Asia hosting the world's $60 \%$ food-insecure people and $75 \%$ of the world's malnourished children [2], had huge task to meet this goal. In Kenya over a quarter of the population is food insecure with majority of them living on relief food supplies. Households also divert a large portion of income to purchase food at the expense of other investments that could include health, clothing, education and businesses. The current teething food insecurity could be attributed to frequent droughts in most parts of the country, high cost of domestic food production as a result of high cost of inputs especially fertilizer, high global food prices and low purchasing power due to poverty.

Apart from the economic, socio-political and institutional constraints, there are also a number of biophysical challenges common among smallholder farmers that contribute to low food production. Inadequate water [3] [4] [5] [6] and poor soils [7] [8] [9] [10] [11] have been commonly linked to low food production in developing countries. In addition, their complementary interaction could lead to poor water partitioning and moisture and nutrient use inefficiency [12] [13] [14] [15]. Rainfed agriculture, commonly linked with these deficiencies is practiced by almost all smallholder farmers due to their inability to obtain or maintain access to reliable and safe water [16]. Kenya is presently vulnerable to hunger due to its reliance on rainfed agriculture that exposes crops to frequent droughts [17].

Land resources are integral components of watershed ecosystems. The wideranging functions and services of watersheds and land resources are, however seriously compromised when these production factors are scarce. Furthermore, watershed management strategies are often challenged by the presence of poor people who typically depend on the natural resources base for their livelihoods. Such is the case in Ombeyi Watershed, Nyando Basin where according to [18], strong links exist between poverty, environment and investment in natural resources. Owing to the growing population pressure, many of the wetlands are 
being converted to more intensive agricultural uses [17]. This decrease in area under wetlands is likely to result in their reduced functionality. Poverty has reduced the use of fertilizer and diminished the use of organic soil enhancement techniques such as contour bunds or improved fallows. Other occupational activities that depend on the extensively committed natural resources include fishing, livestock rearing, trade, beekeeping, brick making, mat making, biotic cover plants harvesting, stone/sand mining and pottery [19] [20].

In the wetland, land and water are the resources being competed for between sustaining livelihoods through crop production and wetland products on one hand and environmental integrity on the other. Although development of irrigation and drainage increases local food production and enhances rural income, it threatens vulnerable wetlands and the ecosystems services that they provide to local inhabitants. According to [21], if the land use trend continued unabated, the increase in papyrus losses will pose a big challenge to the ecological functioning of the wetland and its support to sustaining community livelihoods would be threatened. Irrigated agriculture could also induce soil and water degradation owing to improper use of inputs [22]. Therefore, there is a need to establish a balance that ensures sustainability in the use of the wetland's role to provide for the needs of the community as well as perform its ecological functions. To do this the competing users and uses need to be identified and understood by all stakeholders, management options discussed and agreed upon in a participatory manner and strategies towards sustainable use documented. This path which had not been considered earlier was followed in this study. The paper presents the growth in irrigated agriculture, irrigation practices and existing and potential trade-offs between the various uses of the wetlands and their ecological functions in Ombeyi wetlands. The activities that could ensure the sustainable use of the wetlands from the community's perspective were discussed and documented.

\section{Study Area}

Ombeyi watershed is situated in Kano plains, Nyando drainage basin in Kenya. The main river that provides the water for recharging the wetland ecotone is $\mathrm{R}$. Ombeyi, while Oroba and Nyakoko streams feed this major river and derive its waters from the upper Nandi escarpment which forms its northern boundary (Figure 1). The Ombeyi wetland ecosystem, covering an area of about 1037 ha [23], cuts across the Nyando and Kisumu East Sub-Counties within the Kisumu County and forms a complex ecosystem comprising of several streams, rivers and swamps.

According to [19] the following account holds for the Ombeyi wetlands. Water logging occurs extensively in the plains during and immediately after the rains owing to impended soil drainage due to prevalence of vertic clays. Previously, about $75 \%$ of the plains were viewed unsuitable for economically viable small-scale farming due to the extremely heavy soils combined with a warm climate, relatively low rainfall and repeated flooding which made farming to be 


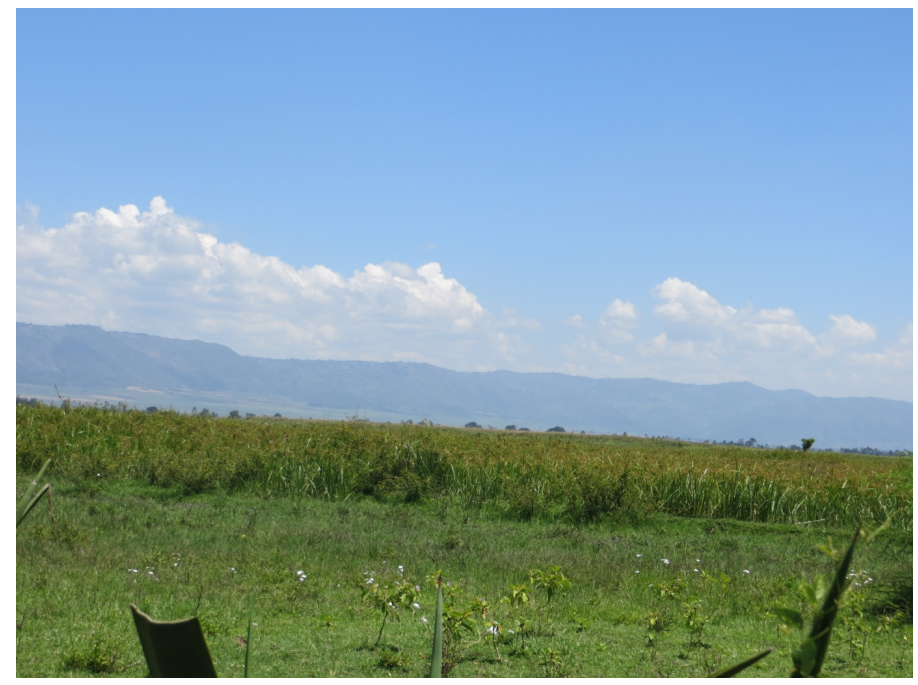

Figure 1. Part of the Ombeyi wetland ecosystem showing the Nandi Escarpment, its northern boundary.

unattractive as an economic venture. However, rice irrigation and recent sugarcane plantations within the wetlands have completely introduced complex hydrological pathways especially as a result of canalization.

\section{Irrigation Development and Practices}

The increasing area under irrigation of various crops was considered largely responsible for the diminishing wetland. Within Ombeyi watershed eleven irrigation clusters, based on villages, were active during the time of this study. These were Kore, Sare, Sanda A, Sanda B, Alungo A, Alungo B, Alungo C, Abwao, Wiswa, Rangenya and Asunda. Each cluster had the current area under cultivation and the maximum area defined by the extent of the ancestral land for the village.

\subsection{Irrigation Expansion}

The actual cultivated and potential irrigable areas in all the clusters were mapped using a GPS. This information was supplemented by historical records held by irrigation management committees dating back to the 1970s. The areas obtained and their potential are illustrated in Table 1.

The analyzed data showed that there has been an increase in area under rice irrigation from a paltry 232 ha in 1970s to 2008 ha during the time of the study. Overall, there has been an increase in irrigation area of about $760 \%$. The area being cultivated represented $62 \%$ of the potential irrigable land. The increase in area under irrigation could be attributed to unreliable rainfall that has seen irrigation as an assurance, the necessity to produce more food per unit area due to the increasing population, the need to cultivate crops with higher market price and the emergence of competitive crops such as sugarcane and arrow roots. In addition, rice cultivation provides a long fallow period that gives livestock the opportunity to graze in the harvested fields. 
Table 1. Actual irrigated area and potential irrigable area in Ombeyi watershed.

\begin{tabular}{ccccccc}
\hline Scheme/Period & 1975 & 1985 & 1995 & 2005 & 2014 & Potential \\
\hline Alungo B & 3 & 100 & 120 & 138 & 150 & 172 \\
Alungo A & 75 & 150 & 166 & 175 & 300 & 480 \\
Alungo C & - & - & - & 10 & 50 & 65 \\
Abwao & - & 100 & 150 & 195 & 200 & 670 \\
Asunda & - & 2 & 65 & 75 & 110 & 205 \\
Rangenya & 5 & 75 & 88 & 100 & 170 & 210 \\
Wiswa & 10 & 40 & 65 & 73 & 100 & 875 \\
Kore & 480 & 700 & 1000 & 2050 & 2302 & 2500 \\
Sanda A & - & - & 7 & 70 & 300 & 360 \\
Sanda B & - & - & 1 & 130 & 330 & 460 \\
Sare & - & 2 & 80 & 130 & 221 & 600 \\
Total acrage & 523 & 1166 & 1735 & 3146 & 4233 & 6597 \\
Area in ha & 212 & 472 & 702 & 1274 & 1714 & 2671 \\
\% decadal increase in area & - & 122.6 & 48.7 & 81.5 & 34.5 & \\
\hline
\end{tabular}

Even though the area under cultivation continually increased, the average yield of most crops declined, as illustrated in Figure 2 [24]. The specific values (tonnes/acre) for 1970, 1980, 1990 and 2000 are highlighted.

The declining average production per unit are in rice is partly due to neglect from farmers as a result of low market prices. Importation of cheap rice, especially from Uganda, was viewed by the farmers as the greatest impediment to attractive market prices. Other factors included use of uncertified seed, no or very low fertilizer use, poor weed control, rice diseases and inadequate water for irrigation due to expansion, poor irrigation water management and competition from sugar cane and arrow root production.

\subsection{Irrigation Water Management}

\subsubsection{Sources of Irrigation Water}

The sources of irrigation water comprise two seasonal rivers, Great Oroba and Little Oroba that are gauged at $1 \mathrm{HA} 01$ and $1 \mathrm{HA} 02$, respectively. The stream flow data for these stations obtained from the Water Resources Authority (WRA) for the period "1970-1999" had numerous gaps, especially for 1HA02 which was thereafter not included in preceding analysis. To address this shortcoming, SWAT model was set up for the watershed using Great Oroba data for calibration and validation. In addition, snapshot discharge measurements were done at five locations over a period of six consecutive weeks. Two sites were selected upstream of the wetland to measure inflows while the other three sites were downstream of the wetland and thus represented outflows from the wetland ecosystem. 


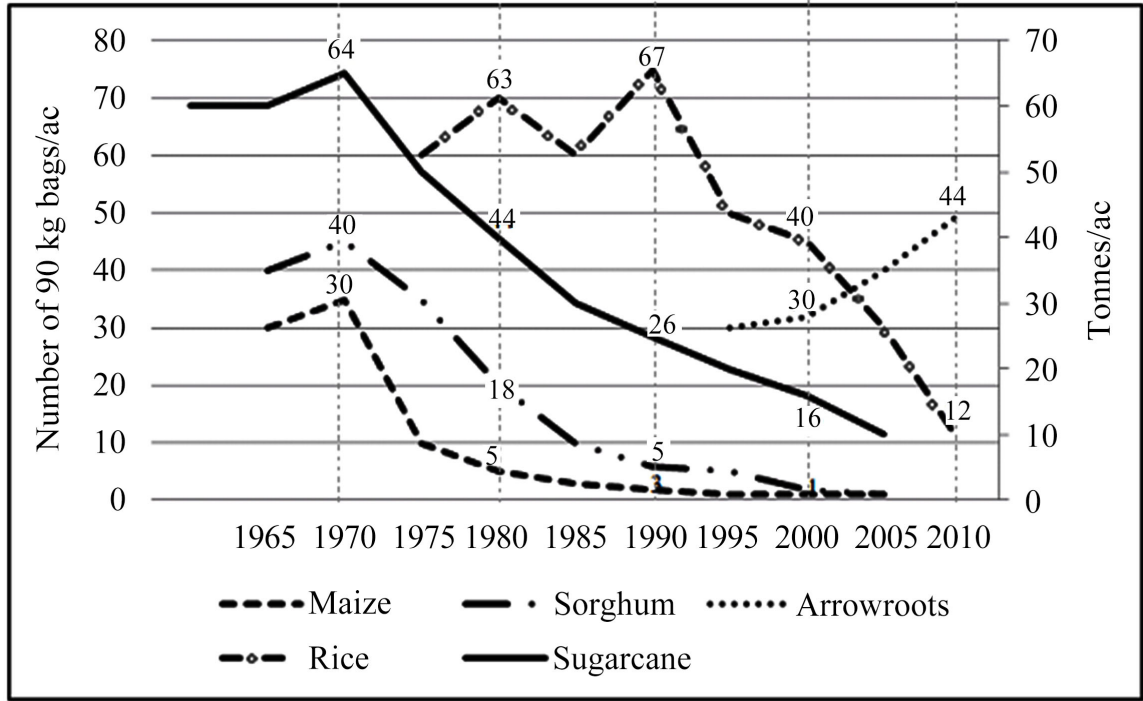

Figure 2. Trends in the average crop production levels (after [24]).

\subsubsection{Scheme Management Committee}

Each of the irrigation schemes in Table 1 is run by an elected committee. The members of the committee are chosen by the farmers to serve for a particular period of time. An overall committee comprising of a member from each scheme committee is mandated to manage irrigation activities in the entire watershed. The formation of these committees is an initiative of the irrigation farmers themselves. Even without the necessary qualities, in some cases influential people lobby their way into such committees. Although it is a mandatory requirement that one has to have land within the specific scheme before seeking a position in the committee, on securing the position a number of them would at times lease out their piece(s) of land or even leave the piece(s) fallow. This is likely to compromise the way the committee deals with scheme matters. For example, the member who has leased out land or left the piece fallow may no longer participate in any further scheme deliberations. Alternatively, the same member may influence committee decisions in favour of the person that leased their land.

The scheme committees neither undergo any training nor have written by-laws to assist them carry out their duties with some level of professionalism. Currently, their role has been passive and reduced to mainly solving disputes between scheme members. The disagreements could be related to boundaries, access to water and/or interference from livestock. Naturally, such committees' mandate is expected to, among other duties, manage the schemes by determining such issues as seasonal cropping calendar, water allocation, source for affordable inputs, link up with extension staff for capacity building, promote best management practices in crop production, ensure compliance with laws and regulations, and identify market outlets. Thus, some of the challenges facing the farmers may possibly be attributed to a weak management system resulting from an incompetent committee. 


\subsubsection{Scheme Water Management}

All the irrigation clusters in Table 1 do not have functional formal irrigation infrastructure. There are no proper water abstractions, conveyance, distribution nor application structures. Figure 3 shows some of the structures serving these purposes. The canals and division boxes (Figure 3(a)) are dilapidated. The absence of control structures such as gates makes the system very inefficient since water flows through the system irrespective of whether it is required or not. Water is also lost through numerous cracks in the canals.

According to [25], productivity in agriculture increases with an effective rural infrastructure, well-functioning domestic markets, appropriate institutions, and access to appropriate technology. At the irrigation scheme level, Farmani et al. (2007) in [26], argued that inadequate investment in appropriate irrigation infrastructure for water abstraction, conveyance, delivery and application including their maintenance lead to numerous water losses. Some studies estimated losses of up to $25 \%$ for delivery systems, as much as $20 \%$ from on-farm pipelines, and a further $10 \%-15 \%$ lost from inefficient water application technologies [26]. The situation is worsened by the increasing pressure to transfer water to other uses, including urban uses and for instream flows to support key ecological assets (Connor, 2008 in [26]).

Many farmers in Ombeyi wetland ecosystem divert water using informal structures which in some cases entail the use of soil (sometimes in sacks) and/or trash from weeding to block the earthen canals so that water enters the desired fields. As shown in Figure 3(b), water losses are still experienced due to leakages through the barriers. Other significant water losses occur due to inadequate water distribution structures. The rice fields are used to convey water to fields that are downstream. Even after harvesting has occurred in some upstream plots, water is still passed through them because transplanting does not occur at the
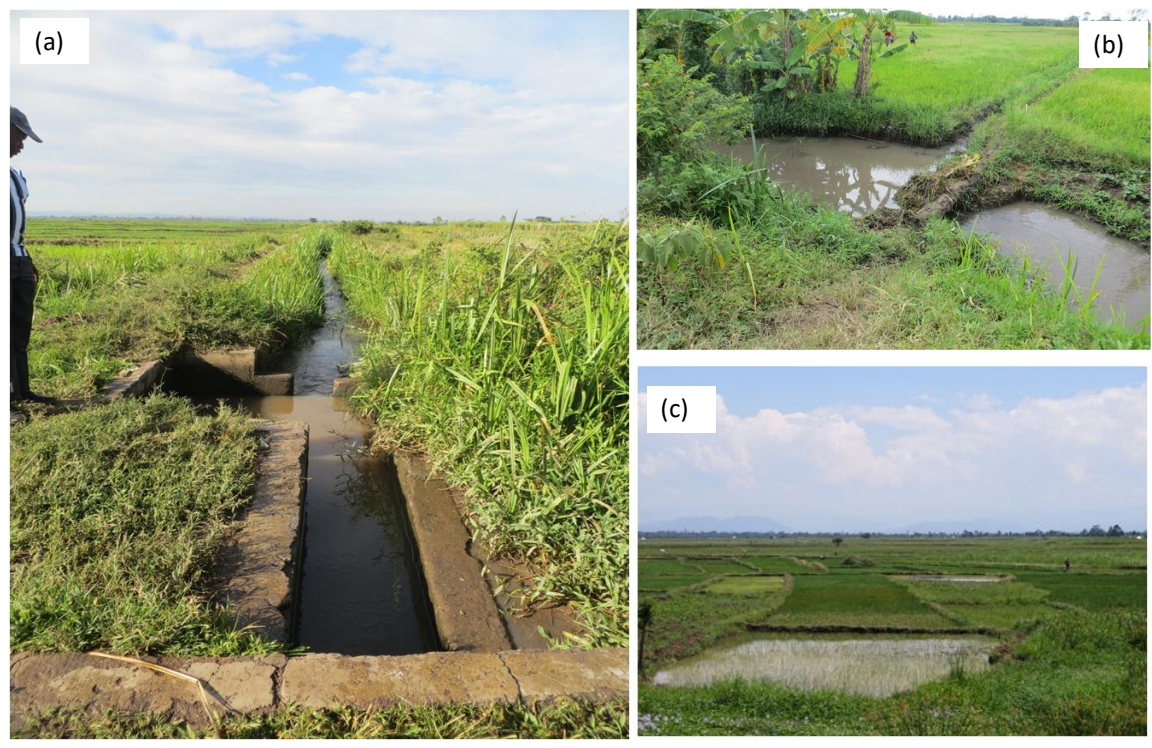

Figure 3. (a) Dilapidated canal and division box; (b) Locally made diversion; and (c) Rice at different growth stages. 
same time due to, among other factors, the lack of a seasonal cropping calendar. Furthermore, the consequences of the recurrent floods in the area disperse field operations. Some farmers are more endowed with resources enabling them to transplant a second time if the first crop is destroyed by floods. Figure 3(c) illustrates fields with rice at different growth stages.

The aforementioned challenges complicate water management. Without proper abstraction infrastructure, the amount of water abstracted could either be too little or too much. However, whenever water is available in the river, coupled with the substantial system losses, farmers are opt for risk aversion and hence the chances of abstracting more water are high. In addition, these farmers are not yet registered into a Water Resource Users' Association (WRUA), a requirement of the WRA, the body charged with regulation of abstractions. This implies that they have no abstraction permits, pay no levies for the water abstracted and thus divert as much as they can so long as water is available in the river.

The presence of an ill-equipped scheme management committee (Section 3.2.1) and the absence of a WRUA suggest that misunderstandings on water allocation are likely to occur frequently as attempts are made to meet the GIR especially when river flows are low. According to the farmers, the lack of a registered WRUA albeit the long period of time that the schemes have been in existence could be attributed to:

1) Ignorance-the farmers are not aware of the functions of a WRUA, their role and the benefits of their participation;

2) The view that WRA is out to exploit the farmers through its mandate of revenue collection;

3) Funding for the association is not forthcoming since the gross margin from the irrigation of rice is currently marginal;

4) Governance issues-after the promulgation of the Kenya Constitution 2010 that led to the creation of a two-tier governance structure, water management was devolved to County governments. This has created confusion among the water managers at District Water Offices, Water Boards, WMA and the newly appointed staff at the County; and

5) There is a frosty working relationship between the managers of water and agriculture at all governance levels. This has negatively affected irrigation activities.

By being non-members of a WRUA, the famers in Ombeyi have not gained the envisioned benefits which according to [27] include the prevention or timely resolution of conflicts arising from water use, protection and conservation of the catchment and the resource, exchange of information and ideas on water resource use, and monitoring of water resource availability, quality and use.

\subsection{Coping Mechanisms}

\subsubsection{Arrow Root Cultivation}

With the recent introduction of arrow roots (Figure 4), more land is likely to be converted to irrigation. This increasing trend in area under arrowroot is being 
(a)

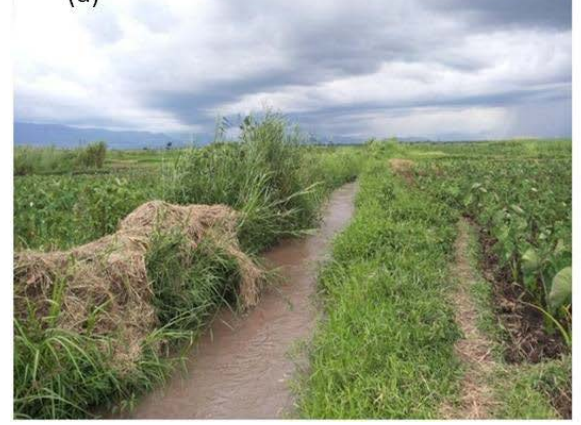

(b)

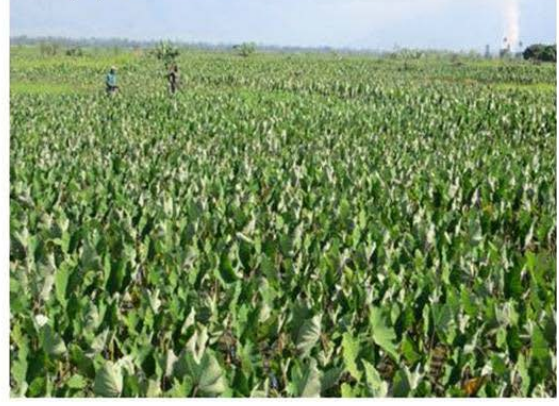

Figure 4. Arrow root cultivation (a) along Oroba River; (b) Largely displacing other crops.

motivated by the increasing average production when that of other crops is exhibiting a declining trend (Figure 2).

On the other hand, arrowroot enjoys high market prices, less labour intensive, have fewer pests and diseases once established, and have a longer harvesting period which enable farmers to:

- Spend less money on harvesting by utilizing only family labour;

- Wait for better prices as opposed to being pressurized by hackers and vendors;

- Have income spread over a longer period of time from the sale of arrow roots; and

- Have food supply for a longer span of time.

Furthermore, as opposed to rice, arrowroot can be grown 1) in soils that rice does not do very well; 2) along river banks that have vegetation (mainly Cyperus papyrus and Phragmites Mauritaianus) that host birds; and 3) throughout the year.

\subsubsection{Off-Farm Income Generating Activities}

Amid the dwindling crop production, safe for arrow root, alternative income generating activities that the farmers have adopted include livestock production, Cyperus papyrus crafts, sand harvesting and fishing. A recent survey (Nasongo et al., 2018) showed that about $91 \%$ of the community engaged in irrigation while $55 \%$ simultaneously did irrigation and harvested wetland products. Those who solely relied on wetland products amounted to a paltry $3 \%$ while $6 \%$ engaged on income generating activities other than irrigation or harvesting wetland products. The alternate livelihood options identified from the survey showed their minimal contribution to household food and/or income since only $9 \%$ of the community did not engage in irrigation activities. In addition, 36\% of the community depended exclusively on crop production through irrigation. This underscores the significance of planning and better managing land and water resources in Ombeyi wetland ecosystem.

\section{Planning and Management of Ombeyi Wetland Ecosystem}

With the recognition that the wetlands were being cleared to pave way to irriga- 
tion of rice and arrow roots, a consultative and participatory approach had to be muted. The community desired knowledge and understanding on how to:

- Protect their livelihood which is dependent on the deteriorating wetland ecosystems; and

- Improve the market value of their products.

\subsection{Constraints, Manifestation and Possible Solutions}

Given that agricultural intensification and/or expansion often increases local food production and enhances rural income, it threatens vulnerable wetlands and the ecosystems services that hitherto provided to locals. There is a need to optimize the co-existence of wetlands and irrigation activities in a sustainable manner. Table 2 gives a summary of the identified constraints and their possible solutions.

\subsection{Planning and Management Options}

As pointed out in Section 3.2.3, farmers abstract as much water as possible and coupled with the numerous system losses that occur due to the dilapidated infrastructure, the amount of water removed from the river is likely to be much higher than the estimated gross irrigation requirement (GIR) of $13.6 \mathrm{~m}^{3} / \mathrm{s}$. This abstraction, which is slightly over $70 \%$ of the river flow, is not sanctioned by law since the farmers do not have an abstraction license. Thus, although the government's food security policy advocates for maximizing land and water resources to produce food, the community's actions seem to be in total contravention of the law. In this study, the farmers were encouraged and guided into forming a WRUA. It is however noted that the process of acquiring the abstraction permit is viewed by many as having so many bureaucracies. There is therefore a need to revise and simplify the procedure to motivate WRUAs and/or individuals to comply with that legal obligation.

Knowledge of the amount of water allocated to each legal entity helps water managers to plan for and oversee the utilization of the resource, among all stakeholders, in an equitable manner. Water to adequately sustain environmental functions should be quantified and included in this arrangement. This quantity is particularly important in the current study since irrigation expansion into wetlands not only consumes additional amount of water but also completely alters the ecological functionality of the converted land. Whereas this study focused only on the gross crop water requirements and the impact of the abstraction on river flow, further work should be directed into the assessment of environmental flow requirements.

In situations where water is scarce and a number of competing uses exist as in this case, water saving opportunities should be sought. The two approaches considered in this study were: 1) optimal cropping calendar and 2) evaluation of various cropping scenarios. It was established that the GIR could be reduced by about $3.5 \mathrm{~m}^{3} / \mathrm{s}$, if rice is transplanted by mid May as opposed to the current 
Table 2. Constraints, manifestation and possible solutions to the unsustainable use of wetlands.

\begin{tabular}{ll}
\hline Constraint & Current status/manifestation \\
\hline & \\
Wetland & -Rampant and widespread encroachment of \\
management & the Ombeyi wetland ecosystem
\end{tabular}

Solution

-Wetland rehabilitation through enforcement of national laws and regulation on wetland management by the relevant authorities -Enforcement of community wetland management laws contained in the recently launched Ombeyi Wetland Management Plan (GoK, 2014)

-Farmers still largely dependent on rainfed agriculture as there is inadequate water

-Alternative sources of water e.g. through water harvesting and storage

-Poor water management within the schemes • Capacity building of farmers and construction of well designed due to the absence of conventional irrigation irrigation and drainage infrastructure

infrastructure leading to water conflicts and $•$ Bottom-up approach in policy formulation in water management low yields

Water -There is flooding caused by runoff from management rains - Repairs of dykes through community initiatives - Farmers to embrace dairy breeds managed under modern techniques such as zero grazing

-There is a lack of pasture for livestock due to $•$ Closer collaboration farmers with key stakeholders-WRA, Lake expansion of irrigation

-Key stakeholders not easily reachable e.g. WRA and National Irrigation Authority (NIA) Victoria Basin Development Authority (LBDA), NIA and others

-Improved public relations between the community and stakeholders

-Institutions to fulfil their social corporate responsibilities

-Currently there is very little value addition being done

-Community to lay down strategies for value addition in collaboration with the respective government officers

-There is lack of co-ordination of farmers in •Formation and registration of farmers' production and marketing the field operations making quality assurance groups

Value addition of produce difficult; hence low returns due to Introduction of new technologies for production of crops and marketing poor marketing value chain

- Farmers should set prices for their produce

-Farmers do not use certified seed and not completely aware of when to plant

- Farmers should use certified seeds and follow the suggested

cropping calendar

-Crop diseases

-Proper agronomic and crop husbandry practices to be adopted

-High production costs

-Best Management Practices and lobbing for subsidy of farm inputs

-The scheme committees are not well trained and are only active at the beginning of the rice planting season

-Arrangements for capacity building to be done through NIA

- Regular meetings, at least on quarterly basis, to be held

Institutional arrangements and resource mobilization

Limited livelihood approaches
-There are many absentee farmers referred to as "Telephone farmers" leading to poor coordination of farming activities -Lack of involvement of National Government (Chiefs and Assistant Chiefs) and relevant agencies in scheme issues -Poor roads and poor sanitation within the schemes due to lack of toilet facilities

-High dependency on cash crop already facing challenges e.g.

1) Rice: poor seeds, crop diseases, high transportation costs and lack of markets

2) Arrowroots: rotting of rhizomes, excessive weeding, pests, middlemen/ brokers and deteriorates soil fertility fast

3) Sugarcane: poor seeds, high transportation costs and poor market value chain
-All farmers including those leasing farms should follow the laid down rules so that farming activities are synchronized -Sanctions to be put on errant persons

- There should be involvement of government officers and relevant agencies e.g. NIA, WRA, LBDA etc. in the scheme activities -Lobby the County government to improve the condition of roads and provide sanitation infrastructure at centres

-Diversification of livelihood strategies through:

-Fish farming

-Dairy farming

-Sale of arts and crafts

e -Establishing horticultural crops

-Starting Eco-tourism ventures

-Sourcing tissue culture bananas from Kenya Agricultural Livestock

Research Organization (KALRO) Kisii and Kakamega

-French bean production for sale via KAVES-USAID 
practice in which farmers transplant in mid July. Arrow root cultivation was found to have more impact on stream flow as compared to rice cultivation. A combination of $60 \%$ area under rice cultivation and $20 \%$ area under arrow root cultivation provided the least relative stream flow impact. Therefore, if these initiatives are incorporated into the community's water management strategy, then the adverse impacts that is posed by the expansion of land under irrigation will have been mitigated to some considerable degree.

The need to transplant rice in mid May demands that nurseries are established in late March to early April. However, during this time, the flow in the river is low. While the intake structures are informal and could be modified to raise the water level to allow flow into the canals, the farmers are not keen to do that due to: 1) fear to create avenues that could divert flood water in the event of sudden heavy storms at the catchment in the beginning of the wet season; 2) livestock are still grazing in the fields at this time and thus nurseries are hard to be managed; and 3) bird menace is rampant at this time since there is very little green vegetation. Subsequently, the necessity for an alternative water source during the dry season for domestic, livestock and agriculture cannot be over emphasized. Rainwater harvesting with storage at the villages or households could be a viable choice to water the rice nurseries, livestock and even some horticultural crops. The storage facilities could be of various capacities and in the form of tanks (masonry and/or plastic) or reservoirs (pans and/or dams) constructed at suitable sites. With these the flooding hazard is likely to be minimized, livestock allowed to graze for a longer duration in the harvested fields and birds can easily be scared away if the nurseries are within the villages/households. By having rice seedlings ready by mid May, the early planting strategy is possible enabling water savings. Extra food and income could be generated from the horticultural crops.

Apart from the expansion of rice into new areas, arrow root cultivation occurred very close to the river banks (Figure 4(a)). According to [28], there exist numerous Acts and by-laws that regulate activities related to rivers and riparian areas. Nonetheless, they prescribe varying distances for riparian reserves. For example the Survey Act takes its measurements from the high water mark level, whereas the Physical Planning and the Water Acts consider the water's edge as the reference. Table 3 provides the statutory provisions of the width of the recommended riparian reserve provided for by various Acts in Kenya.

The discord in the width of the riparian reserve and the diverse reference points for different statutes/institutions, as illustrated in Table 3, is a source of confusion to farmers who could be willing to abide by the law. Even if one was to be found culpable, on which provisions of the law shall the prosecution be based on? The disparities on this single standard demonstrate the possibility of duplication and overlap in service delivery that often precipitate conflict. This study proposes the harmonization of guidelines, policies and laws from the different actors involved in the land-water-environment-food nexus to avoid encroachment into river banks witnessed in Ombeyi wetland ecosystem (Figure 4(a)). 
Table 3. Statutory provisions (Kenya) of the width of riparian reserve.

\begin{tabular}{|c|c|}
\hline Statute/Institution & Recommended width $(\mathrm{m})$ of riparian reserve \\
\hline Water Act (2002) & Minimum $6 \mathrm{~m}$ and maximum $30 \mathrm{~m}$ from edge of the river \\
\hline EMCA (1999) & Minimum $6 \mathrm{~m}$ and maximum $30 \mathrm{~m}$ from edge of the river \\
\hline Agriculture Act & 6 - $10 \mathrm{~m}$; sometimes ad hoc \\
\hline Physical Planning Act & $\begin{array}{l}\text { Minimum } 2 \mathrm{~m} \text { in height and maximum } 30 \mathrm{~m} \text { horizontal from } \\
\text { edge of the river }\end{array}$ \\
\hline Survey Act & $\begin{array}{l}\text { Minimum } 30 \mathrm{~m} \text { for tidal rivers only. No mention of other } \\
\text { smaller rivers. Measurement from high water mark }\end{array}$ \\
\hline Local Government Act & $\begin{array}{l}\text { Ad hoc to a planner's discretion: } 3 \mathrm{~m}, 6 \mathrm{~m} \text {; in some instances } \\
\text { it is taken as equal to the width of the river or twice the width } \\
\text { of the river }\end{array}$ \\
\hline City Council by-laws & Maximum of $30 \mathrm{~m}$ from high water mark \\
\hline
\end{tabular}

Source: Adapted from City Council of Nairobi (2007) in Karisa (2010).

Arrow root does not only consume more water vis-a-vis rice but also can be grown in areas with conditions not favourable to other crops (Section 3.3.2). The increasing yield per unit area of arrow root (Figure 3 ) could be attributed to the newly opened up areas which are still fertile. Unfortunately, farmers observed that arrow root deteriorates the soil fertility very rapidly. This suggests quite soon the production from most of the land currently under cultivation is likely to dwindle to levels that drive the farmers to open new fields, predominantly in the wetlands. Regulation on arrow root production is necessary to reverse these negative effects. For example, soil fertility tests could be made mandatory so that if fertility improvement is necessary and one cannot afford it, then that field is not used to cultivate arrow root during that season. A crop rotation cycle and other Best Management Practices (BMPs) should be adopted by the scheme committees. Another measure would be to introduce a levy or fee that is charged per unit area of land in which arrow root is cultivated. This could limit expansion into new areas and also generate some funds that can support wetland conservation measures.

The community are well aware of the encroachment into the wetlands and is willing to implement the laws on wetland management contained in the recently launched Ombeyi Integrated Wetland Management Plan (GoK, 2014) which they participated in its formulation. This document, developed in conjunction with the National Environmental Management Agency (NEMA), has been adopted by the Kisumu County Government as a reference document for managing wetlands in a sustainable manner. It is hoped that the findings of this study will provide a baseline, framework and targets under which the proposed management plan could be executed.

The over-reliance on irrigation of rice and recently a seemingly unsustainable arrow root production does not guarantee food and income security especially in incidences of high rainfall variability, population growth, limited land and de- 
clining fertility. The requirement for alternative livelihood approaches in Ombeyi watershed was accentuated by the community to boost the current $9 \%$ that depended on activities that are not directly related to irrigation. The proposed options are intended to shoulder household food and income so that less pressure is eventually exerted on the wetland. The most feasible alternatives that could be explored are novel agricultural production technologies such as intensive horticultural production in greenhouses, dairy farming embracing zero grazing, fish farming using fish ponds and sourcing improved cultivars of bananas from certified centres e.g. those managed by KALRO. There are recent attempts by a youth group within the community to produce horticultural crops using harvested rainwater and shallow wells by putting up a greenhouse (Figure 5). The group is also involved in conservation activities supported by Lake Victoria Environment Management Programme (LVEMP II).

Tourism has been one of the highest foreign exchange earners in Kenya for a while. However, the recent security concerns in areas traditionally frequented by tourists, has led to some countries issuing travel advisories which has seen the number of visitors diminishing. There is an opportunity to create alternative tourist destinations. The rich cultural diversity and attractive sites in the region can be of great interest to local and foreign visitors if the right publicity and packaging is done. It is also necessary to developed eco-tourism centres at strategic locations that would serve as market outlets for artefacts and crafts. These approaches are likely to diversify household income and thus relief the current strain experienced by wetland resources.

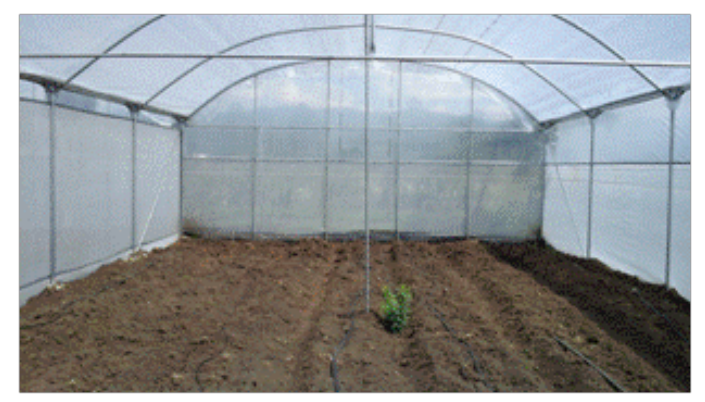

(a)

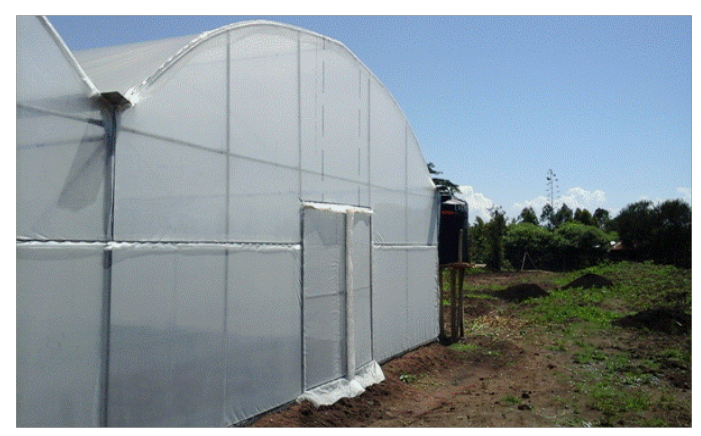

(b)

Figure 5. A greenhouse for youth in Ombeyi in preparation to produce horticultural crops. 
To further promote the sustainable use of wetlands, capacity building of the farmers on various issues of food production, income generation and wetland management should be done. There has been a disparity between production costs and returns. To lower input costs and boost market prices, farmers need to coalesce into production and marketing groups with clear targets, leadership structures and functional by-laws. Pooled procurement of inputs is likely to be cheaper compared to purchases made by individual farmers because it is likely to attract discounts, reduce transport cost and/or could allow payment in instalments. This arrangement could also encourage farmers to produce the same crop varieties at a particular time leading to better market price bargains. Involvement of key partners such as NIAB, LBDA, WRA and the County Government in these engagements will ensure that the right back-stopping is provided, partnerships build and possibly availability of financial support.

\section{Conclusions}

The envisaged broad outcome of this study was to increase knowledge and insights on the co-existence of wetlands and irrigation, identify their synergies and problems, contribute to the policy debate concerning agricultural intensification in wetlands, and strengthen partnerships among stakeholders. The main findings of the study highlighted the evidence of irrigation expansion that could jeopardize the capacity of the wetlands to perform their ecological roles due to reduced water flows into them and the extension of cultivated land into riverine areas and/or those designated as wetlands. The huge dependency on irrigation for food and income generation coupled with the low efficiency of water use and management underscore the need for concerted efforts to reverse the negative effects that are likely to occur in the near future.

The possible solutions to the wetland encroachment and over exploitation of resources may be realized through improving the efficiency in resource use and embracing the suggested alternative livelihood options. It was found out that most approaches on wise use of land and water resources lie with the resource users themselves. Thus, enhancing the capacity of the farmers and their leadership is likely to ensure the efficient utilization of the resources. Mechanisms to implement national policies, rules and regulations should be incorporated into scheme management. The involvement of key partners in every aspect is likely to yield prolonged benefits.

\section{Acknowledgements}

The authors wish to acknowledge the financial support received from UNESCOIHE, Institute of Water Education through the project "Co-management of wetland ecosystems and irrigation for enhancing livelihoods in Lake Victoria Basin (Assignment No. 103864).

\section{Conflicts of Interest}

The authors declare no conflicts of interest regarding the publication of this paper. 


\section{References}

[1] Benson, T. (2005) Africa's Food and Nutritional Security: Where Are We and How Did We Get There? African Technology Development Forum (ATDF) Journal, 2, 18-20. http://www.atdforum.org

[2] Inocencio, A., Sally, H. and Merry, D.J. (2003) Innovative Approaches to Agricultural Water Use for Improving Food Security in Sub-Saharan Africa. International Water Management Institute, Colombo.

[3] Lal, R. (1991) Tillage and Agricultural Sustainability. Soil and Tillage Research, 20, 133-146. https://doi.org/10.1016/0167-1987(91)90036-W

[4] Postel, S. (1999) Pillar of Sand: Can the Irrigation Miracle Last? W.W. Norton and Co., New York.

[5] Seyam, I.M., Hoekstra, A.Y. and Savenije, H.H.G. (2002) Calculation Methods to Assess the Value of Upstream Water Flows and Storage as a Function of Downstream Benefits. Physics and Chemistry of the Earth, 27, 977-982. https://doi.org/10.1016/S1474-7065(02)00101-8

[6] Rockström, J. (2003) Resilience Building and Water Demand Management for Drought Mitigation. Physics and Chemistry of the Earth, 28, 869-877. https://doi.org/10.1016/j.pce.2003.08.009

[7] Foth, H.D. and Ellis, B.G. (1997) Soil Fertility. CRC Publishers, Boca Raton.

[8] Klaij, M.C. and Vachaud, G. (1992) Seasonal Water Balance of Sandy Soil in Niger Cropped with Pearl Millet, Based on Profile Moisture Measurements. Agricultural Water Management, 21, 313-330. https://doi.org/10.1016/0378-3774(92)90053-Y

[9] Fox, P. and Rockström, J. (2000) Water Harvesting for Supplementary Irrigation of Cereal Crops to Overcome Intra-Seasonal Dry Spells in the Sahel. Physics and Chemistry of the Earth Physics and Chemistry of the Earth, 25, 289-296. https://doi.org/10.1016/S1464-1909(00)00017-4

[10] Rockström, J. and Falkenmark, M. (2000) Semi-Arid Crop Production from a Hydrological Perspective-Gap between Potential and Actual Yields. Critical Review of Plant Science, 19, 319-346. https://doi.org/10.1080/07352680091139259

[11] Lafond, G.P., May, W.E., Stevenson, F.C. and Dirksen, D.A. (2006) Effects of Tillage Systems and Rotations on Crop Production for a Thin Black Chernozem in Canadian Prairies. Soil and Tillage Research, 89, 232-245.

https://doi.org/10.1016/j.still.2005.07.014

[12] Rockström, J. (1999) On-Farm Green Water Estimates as a Tool for Increased Food Production in Water Scarce Regions. Physics and Chemistry of the Earth (B), 24, 375-383. https://doi.org/10.1016/S1464-1909(99)00016-7

[13] Gowing, J. (2003) Food Security for Sub-Saharan Africa: Does Water Scarcity Limit the Options? Land Use and Water Resources Research, 3, 2.1-2.7.

[14] Heerink, N. (2005) Soil Fertility Decline and Economic Policy Reform in Sub-Saharan Africa. Land Use Policy, 22, 67-74. https://doi.org/10.1016/j.landusepol.2003.08.002

[15] Breman, H., Groot, R.J.J. and van Keulen, H. (2001) Resource Limitation in Sahelian Agriculture. Global Environmental Change, 11, 59-68. https://doi.org/10.1016/S0959-3780(00)00045-5

[16] Hope, R.A., Jewitt, G.P.W. and Gowing, J.W. (2004) Linking the Hydrological Cycle and Rural Livelihoods: A Case Study in the Luvuvhu Catchment, South Africa. Physics and Chemistry of the Earth, 29, 1209-1217. http://www.africafertilizersummit.org/Background Papers https://doi.org/10.1016/j.pce.2004.09.028 
[17] Osoro, O.N., Obade, P. and Gathuru, G. (2019) Anthropogenic Impacts on Land Use and Land Cover Change in Ombeyi wetland, Kisumu County, Kenya. International Journal of Regional Development, 6, 57-79. https://doi.org/10.5296/ijrd.v6i1.15292

[18] Mungai, D., Swallow, B., Mburu, J., Onyango, L. and Njui, A. (2002) Reversing Environmental and Agricultural Decline in the Nyando River Basin. African Journal of Oral Health Sciences, 3, 97-99.

[19] Kosgei, J.R. (2018) Wetland Characterization and Implications on Agriculture in L. Victoria Basin. In: Singh, V.P., et al., Eds., Water Resources Management, Water Science and Technology Library 78, Springer Nature, Singapore, 251-268. https://doi.org/10.1007/978-981-10-5711-3 18

[20] Ajwang, O.R., Kitaka, N. and Omondi, O.S. (2016) Assessment of Provisioning and Cultural Ecosystem Services in Natural Wetlands and Rice Fields in Kano Floodplain, Kenya. Ecosystem Services, 21, 166-173.

https://doi.org/10.1016/j.ecoser.2016.08.008

[21] Khisa, P.S., Uhlenbrook, S., van Dam, A.A., Wenninger, J., Van Griensven, A. and Abira, M. (2013) Ecohydrological Characterization of the Nyando Wetland, Lake Victoria, Kenya: A State of System (SoS) Analysis. African Journal of Environmental Science and Technology, 7, 417-434. https://doi.org/10.5897/AJEST13.1426

[22] Baï, R., Kouame, I.K., Kouassı, L.K., Konan, S.K. and N’Cho, H.A. (2019) Assessment of the Physicochemical Quality of Irrigation Water and Soil for Sustainable Irrigated Rice Cultivation: Case of Irrigated Perimeter of M'Bahiakro (Central-East of Côte d'Ivoire). Journal of Environmental Protection, 10, 1536-1552. https://doi.org/10.4236/jep.2019.1011091

[23] GoK (2014) Ombeyi Integrated Wetland Management Plan.

[24] Nasongo, S.A.A., de Fraiture, C. and Okeyo-Owuor, J.B. (2018) Trade-Offs between Crop Production and Other Benefits Derived from Wetland Areas: Short-Term Gain versus Long-Term Livelihood Options in Ombeyi Watershed, Kenya. In: Abbink, J., Ed., The Environmental Crunch in Africa: Growth Narratives vs. Local Realities, Palgrave Macmillan, London, 51-83. https://doi.org/10.1007/978-3-319-77131-1 3

[25] Andersen, P. and Shimokowa, S. (2007) Rural Infrastructure and Agricultural Development. The Annual Bank Conference on Development Economics, Tokyo, 29-30 May 2007. http://dirp4.pids.gov.ph/ris/dps/pidsdps1212.pdf

[26] Ward, F.A. (2010) Financing Irrigation Water Management and Infrastructure: A Review. Water Resources Development, 26, 321-349. https://doi.org/10.1080/07900627.2010.489308

[27] GoK (2007) Water Resources Management Rules. Water Resources Management Authority.

[28] Karisa, C. (2010) A Negotiated Framework for Rehabilitation of Riparian Zones in Nairobi City: The Case of Mathare River Valley. The 46th ISOCARP Congress, Nairobi, 19-23 September 2010.

http://erepository.uonbi.ac.ke:8080/xmlui/handle/123456789/45770 